\title{
Dampak Fluktuasi Harga Jagung Terhadap Kesejahteraan Petani Jagung
}

\author{
Rizki Gemala Busyra \\ Program Studi Agribisnis Fakultas Pertanian Universitas Batanghari \\ J1. Slamet Riyadi, Broni Jambi. 36122. Telp.+62741-60103 \\ e-mail : rizki.gemala.busyra@unbari.ac.id
}

\begin{abstract}
Price fluctuation is a common phenomenon that occurs in agricultural products, including corn commodities. The price fluctuation of corn commodity will affect the corn farming condition. If the price of corn falls, the income of corn farmers will also decrease. However, if the price of maize increases, the income of corn farmers will also increase. This study aimed to determine the impact of maize price fluctuations on the welfare of maize farmers in Jambi City. This study used the income and costs analysis method and builds econometric equations for income. This income is an indicator to measure the welfare of farmers. The results showed that the factors affecting the income of maize farmers were seed prices, corn production, maize prices, fertilizer prices and medicine prices. Corn price fluctuations would have an impact on the welfare of corn farmers. Because the statistical value of the price of maize had a significant effect on the income of corn farmers as an indicator of the welfare of corn farmers. If the price of corn rises, the welfare of corn farmers will also increase or vice versa.
\end{abstract}

Keywords: Price Fluctuation, Corn, Farmer Welfare

\begin{abstract}
Abstrak. Fluktuasi harga merupakan suatu fenomena umum yang terjadi pada produk pertanian termasuk komoditas jagung. Fluktuasi harga pada komoditas jagung akan mempengaruhi kondisi usahatani jagung tersebut. Apabila harga jagung turun maka pendapatan petani jagung juga ikut menurun. Namun bila harga jagung meningkat maka pendapatan petani jagung akan meningkat pula. Penelitian ini bertujuan untuk mengetahui dampak fluktuasi harga jagung terhadap kesejahteraan petani jagung di Kota Jambi. Penelitian ini menggunakan metode analisis pendapatan dan biaya serta membangun persamaan ekonometrika untuk pendapatan. Pendapatan ini merupakan salah satu indikator untuk mengukur kesejahteraan petani. Hasil penelitian menunjukkan bahwa faktor-faktor yang mempengaruhi pendapatan petani jagung adalah harga benih, produksi jagung, harga jagung, harga pupuk dan harga obat-obatan. Fluktuasi harga jagung akan berdampak terhadap kesejahteraan petani jagung. Hal ini dikarenakan harga jagung mempunyai pengaruh terhadap pendapatan petani jagung sebagai salah satu indikator kesejahteraan petani jagung. Apabila harga jagung naik maka kesejahteraan petani jagung juga meningkat atau sebaliknya.
\end{abstract}

Kata Kunci: Fluktuasi, Jagung, Kesejahteraan

\section{PENDAHULUAN}

Salah satu komoditas tanaman pangan dunia yang terpenting selain gandum dan padi adalah jagung. Hampir seluruh bagian dari tanaman jagung bernilai ekonomi sehingga jagung dikategorikan sebagai pohon industri (Kemenperin, 2020). Selain untuk bahan makanan pokok, jagung juga digunakan sebagai bahan baku industri, pakan ternak dan bahan farmasi. Mengingat hal tersebut, pemerintah Indonesia telah berupaya untuk selalu meningkatkan produksi jagung Indonesia dengan menjadikan jagung sebagai salah satu dari 11 komoditas strategis yang ditargetkan untuk swasembada. Pada Tahun 2015 Kementerian Pertanian telah mengeluarkan Program UPSUS Pajale untuk meningkatkan produksi tanaman padi, jagung dan kedelai (Busyra, 2016). Pada awal tahun 2020 Kementerian Pertanian melalui Keputusan Menteri Pertanian menjadikan jagung sebagai salah satu komoditas binaan Kementerian Pertanian.

Jambi merupakan salah satu provinsi penghasil jagung di Indonesia. Seluruh kabupaten dan kota yang ada di Provinsi Jambi memproduksi jagung termasuk Kota Jambi. Kota Jambi memiliki luas panen jagung sebesar 93,9 Ha, dengan jumlah produksi sebesar 351,5 Ton (BPS, 2020). Jumlah produksi tanaman jagung ini meningkat dibandingkan tahun sebelumnya.

Produk pertanian yang bersifat musiman ataupun tahunan dapat mempengaruhi pola harga hasil pertanian. Apabila jumlah produksi rendah maka jumlah barang yang akan ditawarkan atau yang tersedia dipasar akan berkurang dan mengakibatkan harga menjadi meningkat, ataupun sebaliknya. Begitu pula dengan komoditas jagung, apabila jumlah jagung yang tersedia dipasar berkurang (akibat produksi yang turun) maka harga akan meningkat. Tetapi apabila jumlah jagung yang tersedia dipasaran meningkat (akibat panen raya) maka harga jagung akan turun. Pada awal tahun 2019 harga jagung menurun karena terjadi panen raya, dan kembali meningkat pada bulan Mei 2019, dan kembali mengalami penurunan pada akhir tahun (Dinas Pertanian, 2019).

Fluktuasi harga merupakan suatu fenomena umum yang terjadi pada produk pertanian termasuk komoditas jagung. Fluktuasi harga pada komoditas jagung akan mempengaruhi kondisi usahatani jagung tersebut. Apabila harga jagung turun maka pendapatan petani jagung juga ikut menurun. Namun bila harga jagung meningkat maka pendapatan petani jagung akan meningkat pula.

Peningkatan pendapatan pada petani jagung diduga akan meningkatkan kesejahteraan petani jagung atau sebaliknya. Hal ini dikarenakan pendapatan merupakan salah satu indikator dalam mengukur tingkat kesejahteraan 
(BPS, 2020). Berdasarkan latar belakang inilah peneliti ingin mengkaji tentang dampak fluktuasi harga jagung terhadap kesejahteraan petani jagung di Kota Jambi.

\section{METODOLOGI PENELITIAN}

Penelitian untuk menganalisis dampak fluktuasi harga jagung terhadap kesejahteraan petani jagung yang dilaksanakan pada tahun 2020. Penelitian dan pengambilan data di lapangan dilaksanakan pada bulan Februari sampai Juli 2020, di Kota Jambi Provinsi Jambi.

Jenis data yang digunakan dalam penelitian ini adalah data rasio. Sumber data yang digunakan adalah data primer dan data sekunder. Data primer berupa data yang diambil langsung dari petani yang terpilih sebagai sampel, pengambilan data dilakukan dengan wawancara langsung pada responden dengan menggunakan daftar pertanyaan yang terpola dan terstruktur sesuai dengan kebutuhan. Data sekunder merupakan data tambahan yang diperoleh dari Dinas Pertanian Provinsi Jambi, Dinas Pertanian dan Ketahanan Pangan Kota Jambi, Badan Pusat Statistik (BPS) Jambi, Badan Pengkajian Teknologi Pertanian (BPTP) Jambi, Dinas Perindustrian dan Perdagangan Provinsi Jambi, dan dari berbagai informasi-informasi lain seperti jurnal-jurnal pertanian, ekonomi dan hasil penelitian terdahulu serta pada beberapa situs di internet. Penelitian dilakukan dengan metode survey.

Pengambilan lokasi penelitian dilakukan secara purposive, yaitu dengan mengambil Kecamatan Alam Barajo sebagai tempat penelitian, dikarenakan wilayah ini memiliki luas tanam, luas panen dan produksi jagung terbesar di Kota Jambi (Dinas Pertanian, 2019). Populasi petani yang mengusahakan tanaman jagung di Kecamatan Alam Barajo berjumlah 67 RTP. Besarnya ukuran sampel yang diambil sesuai dengan pernyataan (Winarno, 2004), bahwa bila populasi cukup homogen, untuk jumlah populasi di bawah 100 dapat digunakan sampel sebesar 50\% dan bila populasi di atas 100 dapat diambil sampel sebesar 15\% dari total populasi petani. Berdasarkan pendapat Winarno tersebut, maka penulis mengambil sampel sebesar 50\% sehingga diperoleh sampel sebanyak 34 RTP. Dengan teknik pengambilan sampel secara acak sederhana (simple random sampling) yang merupakan salah satu teknik pengambilan sampel yang dilakukan dengan cara acak sehingga setiap petani memiliki peluang yang sama untuk dipilih sebagai sampel.

Pendapatan petani jagung merupakan selisih antara total penerimaan dengan total biaya yang digunakan, artinya untuk mendapatkan nilai pendapatan terlebih dahulu dihitung total penerimaan dan total biaya.

Besarnya nilai penerimaan dapat dihitung dengan menggunakan rumus (Hernanto, F, 1996), sebagai berikut :

\section{TR $=$ Hy. $\mathbf{Y}$}

Keterangan :

$\mathrm{TR}=$ Total penerimaan usahatani(Rp/MT)

Hy = Harga satuan produk yang dihasilkan (Rp/Tongkol)

$\mathrm{Y}=$ Jumlah produksi yang dihasilkan (Tongkol/MT)

Untuk menghitung total biaya menggunakan rumus (Kasim, S. A. 2006) sebagai berikut :

\section{$\mathbf{T C}=\mathbf{F C}+\mathbf{V C}$}

Keterangan :

$$
\begin{aligned}
& \mathrm{TC}=\text { Total Biaya }(\mathrm{Rp} / \mathrm{MT}) \\
& \mathrm{FC}=\text { Biaya Tetap }(\mathrm{Rp} / \mathrm{MT}) \\
& \mathrm{VC}=\text { Biaya Variabel }(\mathrm{Rp} / \mathrm{MT})
\end{aligned}
$$

Selanjutnya untuk menghitung pendapatan menggunakan rumus menurut (Soekartawi, 1990) sebagai berikut :

\section{I = TR-TC}

Keterangan :

$$
\begin{array}{ll}
\mathrm{I} & =\text { Total pendapatan usahatani }(\mathrm{Rp} / \mathrm{MT}) \\
\mathrm{TR} & =\text { Total penerimaan }(\mathrm{Rp} / \mathrm{MT}) \\
\mathrm{TC} & =\text { Total Biaya }(\mathrm{Rp} / \mathrm{MT})
\end{array}
$$

Sedangkan untuk menghitung biaya tetap, dihitung dengan nilai penyusutan dan metode garis lurus yang menggunakan rumus Sudarman,A dan Alghifari (2001) yaitu sebagai berikut :

$$
B P A=\frac{D-S}{N}
$$

Keterangan :

$$
\begin{array}{ll}
\mathrm{BPA} & =\text { Biaya Penyusutan Alat }(\mathrm{Rp} / \mathrm{MT}) \\
\mathrm{D} & =\text { Nilai Perolehan }(\mathrm{Rp} / \mathrm{MT}) \\
\mathrm{S} & =\text { Nilai Sisa }(\mathrm{Rp} / \text { Unit })(\text { Asumsi } 0) \\
\mathrm{N} & =\text { Umur Ekonomis }(\mathrm{MT})
\end{array}
$$


Model merupakan suatu penjelas dari fenomena aktual sebagai suatu sistem atau proses (Koutsoyiannis, 1977). Model ekonometrika adalah suatu pola khusus dari model aljabar, yakni suatu unsur yang bersifat stochastic yang mencakup satu atau lebih peubah pengganggu (Intriligator, M.D 1978).

Model ekonometrika merupakan gambaran dari hubungan masing-masing variabel penjelas (explanatory variables) terhadap peubah endogen (dependent variables) khususnya yang menyangkut tanda dan besaran (magnitude and sign) dari penduga parameter sesuai dengan harapan teoritis secara apriori. Model yang baik haruslah memenuhi kriteria teori ekonomi (theoritically meaningful), kriteria statistika yang dilihat dari suatu derajat ketepatan (goodness of fit) yang dikenal dengan koefisien determinasi $\left(\mathrm{R}^{2}\right)$ serta nyata secara statistik (statistically significant) sedangkan kriteria ekonometrika menetapkan apakah suatu taksiran memiliki sifat-sifat yang dibutuhkan seperti unbiasedness, consistency, sufficiency, efficiency. Statistik $\mathrm{D}_{\mathrm{w}}$ adalah salah satu kriteria ekonometrika yang digunakan untuk menguji taksiran, yaitu menguji validitas dari asumsi autocorrelation (Koutsoyiannis, 1977).

Model yang dirumuskan dalam penelitian ini adalah sangat terkait dengan tujuan penelitian yaitu bagaimana dampak fluktuasi harga terhadap kesejahteraan petani jagung. Persamaan yang disusun adalah persamaan pendapatan. Pendapatan petani jagung di Kota Jambi diduga dipengaruhi oleh harga benih jagung, produksi jagung, harga jual jagung, harga pupuk, dan harga obat - obatan.

$\mathrm{I}=\mathrm{a}_{0}+\mathrm{a}_{1} \mathrm{BNH}+\mathrm{a}_{2} \mathrm{QJ}+\mathrm{a}_{3} \mathrm{HJ}+\mathrm{a}_{4} \mathrm{HPU}+\mathrm{a}_{5} \mathrm{HOBT}+\mathrm{U}_{3}$

dimana:

$\begin{array}{ll}\mathrm{I} & =\text { Pendapatan Petani Jagung }(\mathrm{Rp} / \mathrm{MT}) \\ \mathrm{BNH} & =\text { Harga Benih }(\mathrm{Rp} / \mathrm{MT}) \\ \text { QJ } & =\text { Produksi Jagung }(\mathrm{Tongkol} / \mathrm{MT}) \\ \text { HJ } & =\text { Harga Jagung }(\mathrm{Rp} / \mathrm{MT}) \\ \text { HPU } & =\text { Harga Pupuk }(\mathrm{Rp} / \mathrm{MT}) \\ \text { HOBT } & =\text { Harga Obat }- \text { obatan }(\mathrm{Rp} / \mathrm{MT})\end{array}$

Tanda parameter dugaan yang diharapkan:

$\mathrm{a}_{2}, \mathrm{a}_{3}>0 ; \quad \mathrm{a}_{1}, \mathrm{a}_{4}, \mathrm{a}_{5}<0$

Untuk mengetahui dan menguji apakah variabel penjelas secara bersama-sama berpengaruh nyata atau tidak terhadap variabel endogen, maka pada setiap persamaan digunakan uji statistik $\mathrm{F}$, dan untuk menguji apakah masing-masing variabel penjelas berpengaruh nyata atau tidak terhadap variabel endogen, maka pada setiap persamaan digunakan uji statistik t.

Selain itu dilakukan juga uji asumsi klasik yang terdiri dari beberapa uji berikut ini:

\section{a). Uji Multikolinearitas}

Multikolinearitas menandakan bahwa terdapat hubungan linear (korelasi) yang sempurna atau pasti, diantara beberapa atau semua variabel yang menjelaskan dari model regresi (Gujarati, 2003). Model regresi yang baik seharusnya tidak terjadi hubungan linear diantara variabel independen. Menurut Ghozali, I (2008), bahwa untuk mendeteksi ada tidaknya multikolinearitas didalam model regresi adalah sebagai berikut :

- Menganalisis matrik korelasi variabel-variabel independen. Jika antar variabel independen ada korelasi yang cukup tinggi (umumnya di atas 0,90 ), maka hal ini merupakan indikasi adanya multikolinearitas.

- Multikolinearitas dapat juga dilihat dari (1) nilai tolerance dan lawannya (2) Variance Inflation Factor (VIF). Kedua ukuran ini menunjukkan setiap variabel independen manakah yang dijelaskan oleh variabel independen lainnya. Dalam pengertian sederhana setiap variabel independen menjadi variabel dependen dan diregresikan terhadap variabel independen lainnya. Tolerance mengukur variabilitas variabel independen lainnya. Jadi nilai tolerance yang rendah sama dengan nilai VIF yang tinggi (karena VIF=1/nilai tolerance). Nilai cut off yang umum dipakai untuk menunjukkan adanya multikolinearitas adalah nilai tolerance $\leq 0,10$ atau sama dengan nilai $\mathrm{VIF}>10$.

\section{b). Uji Heteroskedastisitas}

Uji heteroskedastisitas digunakan untuk menguji apakah dalam suatu model regresi terjadi ketidaksamaan variance dan residual dari satu pengamatan ke pengamatan yang lain. Jika variance dari residual satu pengamatan ke pengamatan lain tetap, maka disebut homoskedastisitas dan jika berbeda maka disebut heteroskedastisitas (Ghozali I, 2008). Adapun cara untuk mendeteksi ada atau tidaknya heteroskedastisitas menurut Ghozali, I (2008), yaitu dengan melihat grafik scatterplot antara nilai prediksi variabel dependen yaitu ZPRED dengan residualnya SRESID. Deteksi ada tidaknya heteroskedastisitas dapat dilakukan dengan melihat ada tidaknya pola tertentu pada grafik scatterplot dimana sumbu Y adalah Y yang telah diprediksi, dan sumbu X adalah residual (Y prediksi - Y sesungguhnya). Adapun dasar pengambilan keputusan dilakukan dengan dasar analisis sebagai berikut : 
- Jika ada pola tertentu, seperti titik-titik yang ada membentuk pola yang teratur (bergelombang, melebar, menyempit), mengindikasikan telah terjadi heteroskedastisitas.

- Jika tidak ada pola yang jelas, serta titik-titik menyebar diatas dan dibawah angka 0 pada sumbu Y, maka tidak terjadi heteroskedastisitas.

\section{c). Uji Asumsi Normalitas}

Uji asumsi normalitas digunakan untuk menguji apakah dalam suatu model regresi, variabel dependen atau keduanya mempunyai distribusi normal atau mendekati normal (Santoso, 2000). Apabila asumsi ini tidak terpenuhi, baik uji $\mathrm{F}$ ataupun uji-t, dan nilai estimasi nilai variabel dependen menjadi tidak valid (Utomo, 2007). Untuk mendekati normalitas pada model regresi yaitu dengan melihat penyebaran data (titik) pada sumbu diagonal dari grafik normal. Adapun dasar pengambilan keputusannya berdasarkan kriteria uji :

- Jika data menyebar di sekitar garis diagonal dan mengikuti arah garis diagonal, maka model regresi memenuhi asumsi normalitas.

- Jika data menyebar jauh dari garis diagonal dan tidak mengikuti arah garis diagonal, maka model regresi tidak memenuhi asumsi normalitas.

\section{d). Uji Autokorelasi}

Uji autokorelasi adalah salah satu bagian dari uji asumsi klasik dimana suatu persamaan regresi dikatakan telah memenuhi asumsi tidak terjadi autokorelasi dengan menggunakan uji Durbin Watson. Menurut Santoso, S (2000) bahwa tujuan uji autokorelasi adalah untuk mengetahui apakah dalam suatu model regersi linear ada korelasi antara kesalahan pengganggu dengan kesalahan sebelumnya. Apabila hal ini terjadi maka terdapat masakah autokorelasi. Adapun kritik pengujiannya adalah jika $d u<d<4-d u$ maka Ho ditolak yang berarti tidak ada autokorelasi baik positif maupun negatif. Untuk mengetahui ketepatan model regresi sampel dalam menaksir nilai aktualnya dapat diukur dari goodness of fit- nya. Goodness of fit dalam model regresi dapat diukur dari nilai koefisien determinasi, nilai statistik F, dan uji statistik t.

\section{Identitas Petani}

\section{HASIL PENELITIAN}

Dari hasil penelitian dapat diketahui bahwa umur petani berkisar antara 38-78 tahun, dengan rata-rata umur 51,12 tahun. Untuk lebih jelasnya distribusi frekuensi petani berdasarkan kelompok umur dapat dilihat pada Tabel 1 berikut ini :

Tabel 1. Distribusi Frekuensi Petani Jagung Berdasarkan Kelompok Umur

\begin{tabular}{cccc}
\hline No & $\begin{array}{c}\text { Distribusi } \\
\text { Kelompok Umur (Tahun) }\end{array}$ & $\begin{array}{c}\text { Frekuensi } \\
\text { (RTP) }\end{array}$ & Persentase (\%) \\
\hline 1 & $38-44$ & 9 & 26,47 \\
2 & $\mathbf{4 5 - 5 1}$ & $\mathbf{1 1}$ & $\mathbf{3 2 , 3 5}$ \\
3 & $52-58$ & 7 & 20,58 \\
4 & $59-65$ & 3 & 8,82 \\
5 & $66-72$ & 3 & 8,82 \\
6 & $\mathbf{7 3 - 7 9}$ & $\mathbf{1}$ & $\mathbf{2 , 9 4}$ \\
\hline & Jumlah & 34 & 100 \\
\hline
\end{tabular}

Sumber : Data primer yang diolah, Tahun 2020.

Tabel 1 di atas menunjukan bahwa petani yang mempunyai frekuensi paling banyak berada pada kelompok umur 45-51 Tahun yaitu sebanyak 11 RTP dengan persentase 32,35\% dan frekuensi petani paling sedikit adalah kelompok umur 73-79 Tahun dengan jumlah 1 RTP dengan persentase 2,94 \%. Dari data tersebut dapat dikatakan bahwa umur petani jagung merupakan petani yang tergolong produktif. Badan Pusat Statistik (BPS) mendefinisikan kelompok usia produktif yaitu 15-64 tahun. Dengan kondisi petani yang rata-rata berumur produktif maka diharapkan mampu mengolah usahataninya secara maksimal dengan tujuan untuk meningkatkan produksi menjadi optimal.

Dalam penelitian ini tingkat pendidikan yang diukur adalah tingkat pendidikan formal yang pernah diikuti dan diselesaikan oleh petani. Kemauan dan kemampuan petani dalam mengambil keputusan juga dipengaruhi oleh tingkat pendidikan formal petani. Sari Dewi (2010), menyatakan bahwa tingkat pendidikan seseorang dapat mengubah pola pikir, daya penalaran yang lebih baik, sehingga makin lama seseorang mengenyam pendidikan akan semakin rasional. Distribusi frekuensi petani berdasarkan tingkat pendidikan formal dapat dilihat pada Tabel 2 berikut ini: 
Tabel 2. Distribusi Frekuensi Petani Jagung Berdasarkan Tingkat Pendidikan Formal

\begin{tabular}{cccc}
\hline No & $\begin{array}{c}\text { Distribusi } \\
\text { Tingkat pendidikan }\end{array}$ & $\begin{array}{c}\text { Frekuensi } \\
\text { (RTP) }\end{array}$ & Persentase (\%) \\
\hline 1 & SD & 2 & 5,88 \\
2 & SMP & 13 & 38,23 \\
3 & SMA & 19 & 55,88 \\
\hline & Jumlah & 34 & 100 \\
\hline
\end{tabular}

Sumber: Data primer yang diolah, Tahun 2020.

Dari Tabel 2 di atas terlihat jumlah terbanyak berdasarkan tingkat pendidikan formal yang pernah diselesaikan petani adalah SMA yaitu sebanyak 19 RTP (55,88\%). Sedangkan petani yang paling sedikit adalah SD dengan jumlah 2 RTP (5,88\%). Dari tabel di atas dapat ditarik kesimpulan bahwa mayoritas petani menamatkan pendidikan SMA.

Pengalaman berusahatani petani berkisar 7-22 tahun, dengan rata-rata pengalaman berusahatani 11,21 tahun, dapat dilihat pada Tabel 3 berikut ini:

Tabel 3. Distribusi Frekuensi Petani Jagung Berdasarkan Pengalaman Berusahatani

\begin{tabular}{cccc}
\hline No & $\begin{array}{c}\text { Pengalaman Berusahatani } \\
(\text { Tahun })\end{array}$ & $\begin{array}{c}\text { Frekuensi } \\
(\text { RTP) }\end{array}$ & Persentase (\%) \\
\hline 1 & $\mathbf{7 - 9}$ & $\mathbf{1 5}$ & $\mathbf{4 4 , 1 1}$ \\
2 & $10-12$ & 9 & 26,47 \\
3 & $13-15$ & 5 & 14,70 \\
4 & $16-18$ & 2 & 5,82 \\
5 & $19-21$ & 2 & 5,82 \\
6 & $\mathbf{2 2 - 2 4}$ & $\mathbf{1}$ & $\mathbf{2 , 9 4}$ \\
\hline & Jumlah & 34 & 100 \\
\hline
\end{tabular}

Sumber: Data primer yang diolah, Tahun 2020.

Dari Tabel 3 di atas menunjukan bahwa petani yang paling banyak adalah yang telah berusahatani selama 79 tahun dengan jumlah 15 RTP $(44,11 \%)$. Sedangkan yang paling sedikit adalah petani yang berusahatani selama 2224 tahun dengan jumlah 1 RTP $(2,94 \%)$.

Luas lahan yang dimiliki oleh petani akan sangat menentukan pendapatan yang akan diterima oleh petani. Dari hasil penelitian diketahui bahwa luas lahan petani berkisar antara 1.000-12.500 $\mathrm{m}^{2}$, dengan rata-rata luas lahan $3.579,41 \mathrm{~m}^{2}$. Luas lahan yang dimiliki oleh petani dapat dilihat pada Tabel 4 berikut ini:

Tabel 4. Distribusi Frekuensi Petani Jagung Berdasarkan Luas Lahan

\begin{tabular}{cccc}
\hline No & Luas Lahan $\left(\mathrm{m}^{2}\right)$ & $\begin{array}{c}\text { Frekuensi } \\
(\mathrm{RTP})\end{array}$ & Persentase (\%) \\
\hline 1 & & $\mathbf{2 0}$ & $\mathbf{5 8 , 8 2}$ \\
2 & $\mathbf{1 . 0 0 0 - 2 . 9 1 6}$ & 6 & 17,64 \\
3 & $2.917-4.833$ & 4 & 11,76 \\
4 & $4.834-6.750$ & $\mathbf{1}$ & $\mathbf{2 , 9 4}$ \\
5 & $\mathbf{6 . 7 5 1 - 8 . 6 6 7}$ & $\mathbf{1}$ & $\mathbf{2 , 9 4}$ \\
6 & $\mathbf{8 . 6 6 8 - 1 0 . 5 8 4}$ & 2 & 5,88 \\
\hline & $10.585-12.501$ & 34 & 100 \\
\hline
\end{tabular}

Sumber: Data primer diolah, Tahun 2020.

Dari Tabel 4 di atas menunjukan bahwa petani yang paling banyak yaitu petani yang memiliki luas lahan antara 1.000-2.916 $\mathrm{m}^{2}$ dengan jumlah $20 \mathrm{RTP}(58,82 \%)$. Sedangkan petani yang paling sedikit yaitu yang memiliki luas lahan 6.751-8.667 $\mathrm{m}^{2}$ dan 8.668-10.584 $\mathrm{m}^{2}$ dengan jumlah masing-masing $1 \mathrm{RTP}(2,94 \%)$.

\section{Usahatani Jagung di Kota Jambi}

Usahatani jagung di Kota Jambi merupakan salah satu usahatani sampingan setelah ubi kayu dan sayuran seperti kacang panjang dan terong. Kegiatan usahatani jagung dilakukan secara teratur sesuai dengan pola musim tanam, dengan memperhatikan curah hujan dan aspek alam lainnya. Biasanya jika setelah panen jagung dilanjutkan dengan komoditi tanaman lainnya. Lahan yang digunakan dalam usahatani jagung merupakan lahan pribadi.

Varietas benih jagung yang ditanam yaitu Bonanza F1, benih diperoleh dengan membeli di toko pertanian. Sumber modal diperoleh dari modal petani sendiri, dan tenaga kerja diperoleh dari dalam keluarga sehingga tidak mengeluarkan biaya upah. 
Aspek produksi merupakan aspek yang penting dalam kegiatan usahatani jagung. Kegiatan ini dimulai dari persiapan lahan sampai pada tahap pemanenan. Langkah pertama dimulai dengan pembersihan lahan dari rumputrumputan secara manual atau menggunakan parang. Selanjutnya pengolahan tanah yang digemburkan menggunakan cangkul dengan kedalaman 15-20 cm, kemudian dibuat galangan setinggi 20-30 cm, lebar 90-100 cm dan panjang sesuai lahan. Fungsi galangan adalah memudahkan meresapnya air hujan maupun air penyiraman ke dalam tanah serta memudahkan untuk proses pemeliharaan tanaman. Selanjutnya dilakukan proses pemupukan dasar menggunakan pupuk kandang yang diratakan di atas tanah bersamaan dengan pencangkulan untuk meningkatkan kesuburan tanah.

Selanjutnya lahan tersebut digarap dan dipersiapkan untuk penanaman. Tanah ditugal dengan menggunakan tugal yang terbuat dari ranting kayu pohon yang pada bagian bawahnya diruncingkan, dengan rata-rata kedalaman lubang tanam 3-5 cm dan tiap lubang diisi 1-2 butir benih kemudian ditutup kembali dengan tanah. Jarak tanam yang digunakan adalah $75 \times 25 \mathrm{~cm}(75 \mathrm{~cm}$ adalah jarak antar baris dan $25 \mathrm{~cm}$ adalah jarak antar tanaman jagung). Proses pemeliharaan jagung yang dilakukan yaitu dengan secara pemupukan dan pengendalian hama, penyakit dan gulma.

Setelah jagung ditanam, kemudian dilakukan kegiatan pemupukan, pemupukan jagung yang dilakukan menggunakan pupuk kimia NPK, pemupukan pertama dilakukan setelah tanaman berumur \pm 10 hari. Kemudian umur tanaman mencapai \pm 30 hari dilakukan pemupukan kedua, dengan diberikan masing-masing $5 \mathrm{gr} / \mathrm{tanaman}$ dengan jarak yang diberikan dari pangkal batang yaitu $10 \mathrm{~cm}$. Pemupukan dilakukan dua kali dalam satu kali musim tanam.

Kemudian petani menggunakan obat-obatan dengan dosis sesuai dengan jenis obat berupa Amistartop, Extratin, Nopatex, Dursban, Gramoxone dan Regent, pengendalian dilakukan tergantung pada keadaan tanaman pengganggu (gulma). Umumnya petani menggunakan dengan air 10 liter kedalam handsprayer yang dilakukan dengan interval 2-3 hari menggunakan handsprayer dengan cara disemprotkan. Titik kerawanan penyakit pada tanaman jagung yaitu menyerang tanaman muda sampai \pm 45 hari. Sementara pengendalian hama dan penyakit dilakukan apabila gejala serangan mulai tampak, hama yang sering mengganggu pada tanaman jagung adalah ulat daun, penggerek daun, ulat tongkol, sedangkan penyakit jagung yaitu bulai dan bercak daun dengan daun pada tanaman menjadi kuning keputih-putihan.

Umur panen jagung sekitar $\pm 70-85$ HST (Hari Setelah Tanam), umumnya jumlah jagung per batang yaitu satu tongkol dengan jumlah rata-rata produksi jagung 5.929,412 tongkol/MT. Selanjutnya kegiatan pemanenan yaitu dilakukan secara manual dengan cara memetik tongkol menggunakan tangan atau sabit dengan memotong tangkai buah. Selanjutnya adalah kegiatan pasca panen yang meliputi kegiatan penyortiran yang dilakukan di lahan untuk membedakan jagung yang bermutu dengan yang tidak bermutu dapat dilakukan dengan mengamati pada bagian luar jagung, lalu jagung yang tidak bermutu atau tidak layak dijual di konsumsi sendiri, selanjutnya penyimpanan dapat dilakukan dengan dimasukkan kedalam karung.

Setelah mendapatkan output produksi berupa jagung segar kegiatan selanjutnya adalah pemasaran, pemasaran jagung dilakukan dengan cara konsumen datang langsung ke petani, sehingga petani tidak perlu biaya untuk memasarkan hasil. Harga jagung adalah Rp.1.500/tongkol. Adapun sistem pembayaran yang dilakukan secara tunai.

\section{Biaya Produksi, Penerimaan dan Pendapatan Petani Jagung di Kota Jambi}

Biaya produksi pada usahatani jagung adalah jumlah total dari biaya tetap (fixed cost) dan biaya tidak tetap (variabel cost). Biaya tetap adalah biaya yang harus dikeluarkan petani dalam proses produksi dan tidak habis dalam satu kali proses produksi. Biaya tidak tetap adalah biaya yang digunakan dalam proses produksi dan habis satu kali produksi.

Pada usahatani yang dikelola petani, biaya tetap disini adalah biaya penyusutan yang dihitung berdasarkan nilai ekonomis alat-alat digunakan terdiri dari: cangkul, parang, sabit, karung, handsprayer. Sedangkan biaya tidak tetap terdiri dari biaya pembelian benih, pupuk kandang, pupuk NPK, Obat-obatan. Untuk lebih jelasnya rata-rata jumlah komponen biaya dalam usahatani jagung dapat dilihat pada Tabel 5. 


\section{Tabel 5. Rata-rata Komponen Biaya Produksi pada Usahatani Jagung}

\begin{tabular}{|c|c|c|c|}
\hline No & $\begin{array}{c}\text { Komponen } \\
\text { Biaya Produksi }\end{array}$ & $\begin{array}{c}\text { Biaya } \\
(\mathrm{Rp} / \mathrm{MT})\end{array}$ & $\begin{array}{c}\text { Persentase } \\
(\%)\end{array}$ \\
\hline I. & Biaya Tetap & & \\
\hline 1 & Cangkul & 7.184 & 0,48 \\
\hline 2 & Parang & 4.967 & 0,33 \\
\hline 3 & Sabit & 4.951 & 0,33 \\
\hline 4 & Karung & 18.960 & 1,28 \\
\hline \multirow[t]{2}{*}{5} & Handsprayer & 24.608 & 1,66 \\
\hline & Jumlah I & 60.670 & 4 \\
\hline II. & Biaya Variabel & & \\
\hline 1 & Benih & 780.000 & 52,67 \\
\hline 2 & Pupuk Kandang & 70.882 & 4,78 \\
\hline 3 & Pupuk NPK & 415.059 & 28,02 \\
\hline \multirow[t]{3}{*}{4} & Obat-obatan & 154.265 & 10,41 \\
\hline & Jumlah II & 1.420 .206 & 96 \\
\hline & Jumlah I+II & 1.480 .876 & 100 \\
\hline
\end{tabular}

Sumber: Data primer yang diolah, Tahun 2020.

Berdasarkan Tabel 5 di atas dapat dilihat bahwa biaya produksi adalah pada komponen biaya tidak tetap yaitu sebsesar Rp.1.420.206/MT. Selanjutnya jika dilihat dari jumlah komponen biaya tidak tetap tersebut, yang paling besar digunakan untuk biaya benih yaitu sebesar Rp.780.000/MT dan yang paling kecil terdapat pada biaya pupuk kandang yaitu sebesar Rp.70.882,35/MT. Sedangkan untuk biaya tetap yang paling kecil terdapat pada biaya sabit yaitu sebesar Rp. 4.951/MT dan yang paling besar terdapat pada biaya handsprayer yaitu sebesar Rp. 24.608/MT dengan total Rp.60.670/MT.

Penerimaan usahatani dapat terwujud tiga hal yaitu hasil produk, produk yang dikonsumsi keluarga dan kenaikan investasi. Tjakrawiralaksana,A (1987), menyatakan penerimaan usahatani adalah besarnya output usaha baik produk utama maupun produk sampingan yang dihasilkan, baik digunakan untuk bibit atau dapat terwujud tiga hal yaitu hasil produk, produk yang dikonsumsi keluarga dan kenaikan investasi.

Penerimaan usahatani jagung adalah hasil dari produksi dikali dengan harga jual produk. Besarnya penerimaan tergantung dari harga pada saat produksi di pasarkan. Harga penjualan jagung pada saat penelitian adalah Rp.1.500/Tongkol, dengan rata-rata produksi jagung 5.929,412 tongkol/MT. Untuk mengetahui besarnya rata-rata penerimaan petani pada usahatani jagung dapat dilihat pada Tabel 6 berikut:

Tabel 6. Rata-rata Penerimaan Petani pada Usahatani Jagung

\begin{tabular}{clc}
\hline No & \multicolumn{1}{c}{ Uraian } & Jumlah \\
\hline 1 & Produksi (tongkol/MT) & $5.929,412$ \\
2 & Harga (Rp/tongkol) & 1.500 \\
3 & Penerimaan (Rp/MT) & 8.894 .118 \\
\hline
\end{tabular}

Sumber: Data primer yang diolah, Tahun 2020.

Berdasarkan Tabel 6 di atas dapat dilihat bahwa rata-rata penerimaan petani pada usahatani jagung adalah sebesar Rp.8.894.118/MT. Jumlah tersebut di dapat dari jumlah produksi dikali dengan harga akan mendapatkan penerimaan.

Pendapatan usahatani dapat diukur dari selisih total penerimaan dengan total biaya produksi. Pendapatan yang dihitung adalah dari hasil produksi dikali harga jual produk, dan dikurangi dengan total biaya produksi dihitung dalam satuan rupiah per musim tanam. Untuk mengetahui besarnya rata-rata jumlah pendapatan petani pada usahatani jagung dapat dilihat pada Tabel 7.

Tabel 7. Rata-rata Pendapatan Petani Sampel pada Usahatani Jagung

\begin{tabular}{ccc}
\hline No & Uraian & Jumlah \\
\hline 1 & Penerimaan (Rp/MT) & 8.894 .118 \\
2 & Biaya Produksi (Rp/MT) & 1.480 .876 \\
3 & Pendapatan (Rp/MT) & 7.413 .242 \\
\hline
\end{tabular}

Sumber: Data primer yang diolah, Tahun 2020.

Berdasarkan Tabel 7 di atas dapat dilihat bahwa rata-rata pendapatan petani pada usahatani jagung di Kota Jambi adalah sebesar Rp.7.413.242/MT, dengan rata-rata lahan yang seluas 3.579,41 $\mathrm{m}^{2}$. Jika dilihat dari tingkat 
kesejahteraan, maka petani di Kelurahan Bagan Pete sudah tergolong sejahtera, karena nilai pendapatan petani jagung di Kelurahan Bagan Pete yaitu sebesar Rp.2.471.080/bulan. Nilai tersebut berada di atas Upah Minimum Regional (UMR) sebesar Rp.2.423.889/bulan (Disnakertrans Provinsi Jambi, 2018).

\section{Analisis Dampak Fluktuasi Harga Jagung Terhadap Kesejahteraan Petani Jagung}

Salah satu indikator untuk mengukur kesejahteraan petani jagung adalah dengan melihat pendapatannya. Maka perlu dilihat faktor-faktor yang mempengaruhi pendapatan petani terdiri atas harga benih jagung, produksi jagung, harga jual jagung, harga pupuk, dan harga obat-obatan. Dalam pengelolaannya perlu diketahui bahwa penggunaan faktor-faktor ini berpengaruh atau tidak terhadap pendapatan petani jagung di daerah penelitian. Untuk mengetahui pengaruh tersebut digunakan model ekonometrika dengan persamaan regresi linear berganda dengan bantuan alat analisis program SPSS. Sebelum dilakukan estimasi model regresi berganda tersebut, data yang digunakan harus dipastikan terbebas dari penyimpangan asumsi klasik diantaranya uji multikolinearitas, heteroskesdasitas, normalitas dan autokorelasi. Hasil uji asumsi klasik dalam penelitian ini adalah sebagai berikut :

\section{A. Hasil Uji Asumsi Klasik \\ a). Uji Multikolinearitas}

Uji multikolinearitas adalah digunakan untuk mengetahui apakah terjadi hubungan antar variabel independen dengan variabel independen lainnya. Apabila hal ini terjadi, maka terjadi masalah multikolinearitas sebab model regresi yang baik seharusnya tidak terjadi korelasi diantara variabel independennya. Berdasarkan hasil analisis data uji multikolinearitas dengan menggunakan nilai VIF dan nilai tolerance menunjukan tidak terjadi multikolinearitas pada model regresi, untuk lebih jelas dapat dilihat pada Tabel 8.

Tabel 8. Hasil Uji Multikolinearitas dengan menggunakan Nilai VIF

\begin{tabular}{cccl}
\hline Variabel & Tolerance & Nilai VIF & Keterangan \\
\hline Harga Benih $\left(\mathrm{X}_{1}\right)$ & 0,276 & 1.665 & Tidak terjadi Multikolinearitas \\
Produksi Jagung $\left(\mathrm{X}_{2}\right)$ & 0,375 & 7.342 & Tidak terjadi Multikolinearitas \\
Harga Jagung $\left(\mathrm{X}_{3}\right)$ & 0,346 & 6.721 & Tidak terjadi Multikolinearitas \\
Harga Pupuk $\left(\mathrm{X}_{4}\right)$ & 0,415 & 4.347 & Tidak terjadi Multikolinearitas \\
Harga Obat-obatan $\left(\mathrm{X}_{5}\right)$ & 0,218 & 5.212 & Tidak terjadi Multikolinearitas \\
\hline
\end{tabular}

Sumber : Data Primer yang Diolah, Tahun 2020

\section{b). Uji Heteroskedastisitas}

Uji heteroskedastisitas digunakan untuk menguji apakah dalam suatu model regresi terjadi ketidaksamaan variance dan residual dari satu pengamatan ke pengamatan yang lain. Jika variance dari residual satu pengamatan ke pengamatan lain tetap, maka disebut homoskedastisitas, namun apabila berbeda maka tidak terjadi heteroskedastisitas.

Berdasarkan keterangan pada Gambar 1, dapat diketahui bahwa tidak terjadi heteroskedastisitas. Hal ini disebabkan karena tidak ada pola yang jelas serta titik-titik menyebar di atas dan di bawah angka 0 pada sumbu Y, sehingga dapat dikatakan uji heteroskedastisitas terpenuhi.

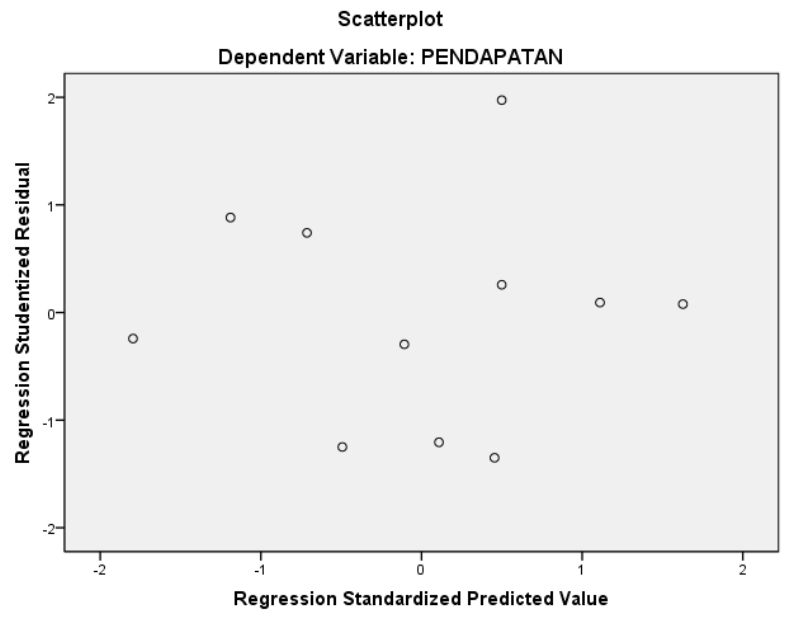

Gambar 1. Grafik Scatterplot Hasil Uji Heteroskedastisitas 


\section{c). Uji Normalitas}

Uji asumsi normalitas digunakan untuk menguji apakah dalam suatu model regresi, varibel dependen atau keduanya mempunyai distribusi normal atau mendekati normal (Santoso, 2000). Berdasarkan penjelasan tersebut bahwa Apabila asumsi normalitas tidak terpenuhi maka baik uji $\mathrm{F}$ ataupun uji-t, dan nilai estimasi nilai variabel dependen menjadi tidak valid. Berdasarkan keterangan Gambar 2, bahwa terlihat titik-titik yang menyebar disekitar garis diagonal serta penyebarannya mengikuti garis tersebut. Dari hasil tersebut dapat disimpulkan bahwa model regresi yang digunakan telah memenuhi asumsi normalitas.

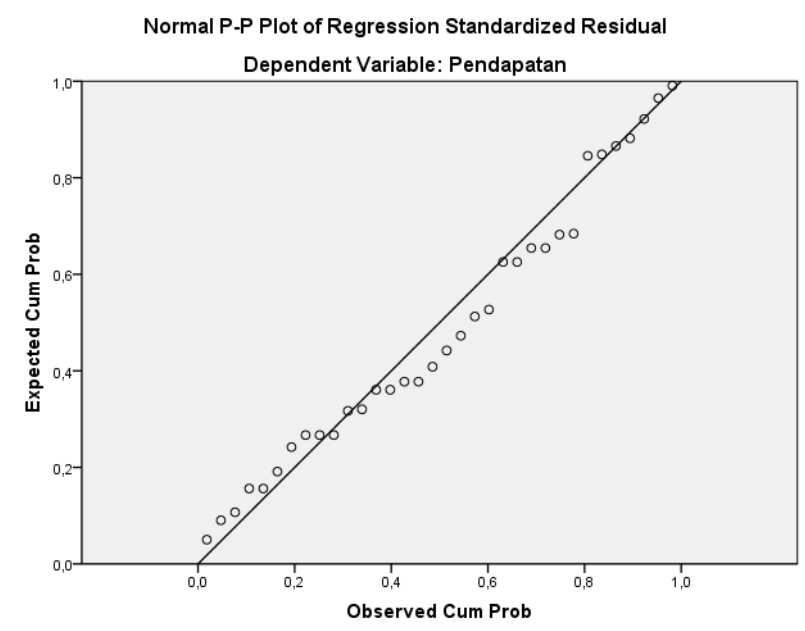

Gambar 2. Gambar Grafik Normal P-Plot

\section{d). Uji Autokorelasi}

Menurut Santoso, S (2000) bahwa tujuan uji autokorelasi adalah untuk mengetahui apakah dalam suatu model regresi linear ada korelasi antara kesalahan pengganggu dengan kesalahan sebelumnya. Hasil pengujian terhadap model regresi yang dilakukan tidak terdapat autokorelasi, karena nilai DW sebesar 1,937 lebih besar dari batas atas (du) 1,81 dan kurang dari 2 .

\section{B. Pengujian Hipotesis}

Hasil uji asumsi klasik regresi linear berganda untuk mengetahui pengaruh variabel bebas (independen) yaitu harga benih, produksi jagung, harga jagung, harga pupuk, dan harrga obat-obatan terhadap variabel terikat (dependen) atau pendapatan petani jagung, dapat dilihat pada Tabel 9.

\section{Tabel 9. Hasil Analisis Regresi Pendapatan Petani Jagung}

\begin{tabular}{lccc}
\hline \multicolumn{1}{c}{ Variabel } & Koefisien Regresi & t hitung & Sig \\
\hline Konstanta & 3,955 & 9,054 & 0,001 \\
Harga Benih $\left(\mathrm{X}_{1}\right)$ & $-1,020$ & $-9,680$ & 0,003 \\
Produksi Jagung $\left(\mathrm{X}_{2}\right)$ & 1422,155 & 8,289 & 0,015 \\
Harga Jagung $\left(\mathrm{X}_{3}\right)$ & 4,024 & 3,582 & 0,021 \\
Harga Pupuk $\left(\mathrm{X}_{4}\right)$ & $-0,416$ & $-5,260$ & 0,032 \\
Harga Obat-Obatan $\left(\mathrm{X}_{5}\right)$ & $-1,041$ & $-3,513$ & 0,002 \\
\hline Adjusted R ${ }^{2}$ Square $=0,998$ & $\mathrm{~F} \quad \mathrm{t}_{\text {tabel }} \alpha_{0,05}=1,69$ & & \\
Hitung $=331.296$ & & Taraf kepercayaan $95 \%$ & \\
$\mathrm{~F}_{\text {tabel }} \alpha_{0,05}=2,558$ & & & \\
\hline
\end{tabular}

Sumber : Data Primer yang Diolah, Tahun 2020

Berdasarkan hasil analisis regresi pada Tabel 9 di atas, diperoleh persamaan regresi:

$$
\mathrm{Y}=3,955-1,020 \mathrm{X}_{1}+1422,155 \mathrm{X}_{2}+4,024 \mathrm{X}_{3}-0,416 \mathrm{X}_{4}-1,041 \mathrm{X}_{5}+\mathrm{e}
$$

\section{a). Analisis Uji Keragaman (Uji F)}

Analisis uji $\mathrm{F}$ digunakan untuk menguji variabel independen yang terdiri atas harga benih, produksi jagung, harga jagung, harga pupuk, dan harga obat-obatan berpengaruh terhadap jumlah pendapatan petani jagung. Berdasarkan hasil uji $\mathrm{F}$ yang telah dilakukan melalui pengolahan data menggunakan program SPSS, diperoleh nilai $\mathrm{F}_{\text {hit }}$ sebesar $331.296>$ nilai $\mathrm{F}_{\text {tabel }}$ : $(\alpha=0,05)(\mathrm{d}=5 ; 28)$ sebesar 2,558 , artinya bahwa secara bersama-sama dari semua variabel independen (harga benih, produksi jagung, harga jagung, harga pupuk, dan harga obat-obatan) berpengaruh terhadap variabel dependen (pendapatan petani jagung). 


\section{b). Analisis Uji Koefisien Determinasi $\left(\mathbf{R}^{2}\right)$}

Uji koefisien determinasi menunjukkan seberapa baik variabel-variabel bebas menjelaskan hasil (multiple correlation coefficient). Dalam penelitian ini, nilai Adjusted $\mathrm{R}^{2}=0,998$ atau 99,8\% menunjukkan bahwa kemampuan variabel bebas dalam memberikan informasi untuk menjelaskan keragaman variabel terikat relatif tinggi. Sehingga dapat disimpulkan bahwa variabel bebas (harga benih, produksi jagung, harga jagung, harga pupuk, dan harga obat-obatan) memiliki pengaruh yang besar terhadap peningkatan maupun penurunan pendapatan petani jagung dan sisanya sebesar $0,2 \%$ tidak dijelaskan oleh model, akan tetapi dijelaskan oleh faktor lain. Apabila dilihat secara keseluruhan bahwa model yang digunakan dalam penelitian ini cukup baik.

\section{c). Analisis Koefisien Regresi (Uji t)}

Dalam persamaan regresi suatu penelitian, nilai koefisien pada masing-masing variabel independen (harga benih, produksi jagung, harga jagung, harga pupuk, dan harga obat-obatan) harus melalui pengujian secara satu persatu, hal ini bertujuan untuk mengetahui variabel independen yang mana yang memiliki pengaruh nyata terhadap variabel dependen (pendapatan petani jagung). Adapun hasil dan pembahasan uji signifikansi akan dijelaskan sebagai berikut :

\section{Harga Benih}

Nilai thit pada variabel benih $-9,680<$ nilai tabel sebesar $-1,96$, maka secara statistik harga benih berpengaruh nyata terhadap pendapatan petani jagung. Nilai koefisien regresi sebesar $-1,020$ menunjukkan bahwa penurunan harga benih sebesar Rp. 1/Kg akan meningkatkan pendapatan petani jagung sebesar Rp. 1,020/MT, dengan asumsi faktor yang lain dalam keadaan konstan. Semakin besar penurunan harga benih maka akan meningatkan pendapatan

\section{Produksi Jagung}

Nilai $t_{\text {hitung }}$ pada variabel produksi jagung 8,289 > nilai tabel sebesar 1,96, maka secara statistik jumlah produksi jagung berpengaruh nyata terhadap pendapatan petani jagung. Nilai koefisien regresi sebesar 1422,155 menunjukkan bahwa penambahan jumlah produksi jagung sebesar $1 \mathrm{Kg} / \mathrm{MT}$ akan meningkatkan pendapatan petani jagung sebesar Rp. 1.422,155/MT, dengan asumsi faktor yang lain dalam keadaan konstan. Semakin besar jumlah produksi jagung yang dihasilkan, maka pendapatan petani jagung akan semakin tinggi

\section{Harga Jagung}

Nilai $t_{\text {hitung }}$ pada variabel harga jagung 3,582 > nilai $t_{\text {tabel }}$ sebesar 1,96, maka secara statistik harga jagung berpengaruh nyata terhadap pendapatan petani jagung. Berdasarkan hasil penelitian yang dilakukan, nilai koefisien regresi sebesar 4,024 menunjukkan bahwa peningkatan harga jagung sebesar Rp. 1/Kg akan meningkatkan pendapatan petani sebesar Rp. 4,024/MT, dengan asumsi faktor yang lain dalam keadaan konstan.

\section{Harga Pupuk}

Nilai $t_{\text {hitung }}$ pada variabel harga pupuk $-5,260<$ nilai $t_{\text {tabel }}$ sebesar $-1,96$, maka secara statistik harga pupuk berpengaruh nyata terhadap pendapatan petani jagung. Berdasarkan hasil penelitian, nilai koefisien regresi pada variabel harga pupuk adalah sebesar -0,416 menunjukkan bahwa peningkatan harga pupuk sebesar Rp. 1/Kg akan menurunkan pendapatan petani jagung Rp. 0,416/MT, dengan asumsi faktor yang lain dalam keadaan konstan.

\section{Harga Obat-Obatan}

Nilai $t_{\text {hitung }}$ pada variabel harga obat-obatan $-3,513<$ nilai $t_{\text {tabel }}$ sebesar $-1,96$, maka secara statistik harga obatobatan berpengaruh nyata terhadap pendapatan petani jagung. Berdasarkan hasil penelitian, nilai koefisien regresi pada variabel harga obat-obatan adalah sebesar -1,041 menunjukkan bahwa peningkatan harga obat-obatan sebesar Rp. 1/Liter akan menurunkan pendapatan petani jagung Rp. 1,041/MT, dengan asumsi faktor yang lain dalam keadaan konstan.

\section{C.Fluktuasi Harga Jagung Terhadap Kesejahteraan Petani Jagung}

Salah satu indikator untuk melihat kesejahteraan petani jagung dapat dilihat dari pendapatan yang diterima petani jagung tersebut. Pendapatan petani jagung sangat erat kaitannya dengan harga jagung yang dijual oleh petani tersebut. Hal ini sudah terbukti dari hasil perhitungan pada sub bab di atas dimana harga jagung sangat berpengaruh nyata terhadap pendapatan petani jagung.

Hubungan antara harga jagung dan pendapatan petani jagung berbanding lurus. Maksudnya adalah ketika harga jagung naik maka pendapatan petani jagung juga meningkat, dan sebaliknya jika harga jagung turun maka pendapatan petani juga iut menurun. dan kesejahteraan petani jagung.

Dari perhitungan di atas dapat diketahui bahwa apabila terjadi peningkatan harga jagung sebesar Rp. $1 / \mathrm{Kg}$ akan meningkatkan pendapatan petani sebesar Rp. 4,024/MT atau sebaliknya, dengan asumsi faktor yang lain dalam keadaan 
konstan. Harga jagung di Indonesia cenderung tidak stabil, hal ini dapat dilihat dari fluktuasi harga jagung setiap bulannya. Sewaktu panen raya maka harga jagung akan turun dan ketika musim hujan maka harga jagung akan naik. Fluktuasi harga jagung ini pun akan berdampak bagi pendapatan petani. Dari hasil perhitungan apabila harga jagung meningkat sebesar Rp. 8/Kg maka pendapatan petani pun akan meningkat sebesar Rp. 32,192/MT, dan apabila harga jagung turun sebesar Rp. 5/Kg maka pendapatan petani pun akan turun sebesar Rp. 20,120/MT. Oleh sebab itu naik turunnya harga jagung akan berdampak pada naik turunnya pendapatan petani.

\section{KESIMPULAN} berikut:

Berdasarkan hasil penelitian yang telah dikemukakan di atas, maka dapat ditarik beberapa kesimpulan sebagai

Faktor-faktor yang mempengaruhi pendapatan petani jagung adalah harga benih, produksi jagung, harga jagung, harga pupuk dan harga obat-obatan.

Fluktuasi harga jagung akan berdampak terhadap kesejahteraan petani jagung. Hal ini dikarenakan harga jagung mempunyai pengaruh terhadap pendapatan petani jagung sebagai salah satu indikator kesejahteraan petani jagung. Apabila harga jagung naik maka kesejahteraan petani jagung juga meningkat atau sebaliknya.

\section{DAFTAR PUSTAKA}

A.T. Mosher. 1987. Menggerakkan Dan Membangun Pertanian. Yasaguna. Jakarta.

Badan Pusat Statistik Provinsi Jambi. 2020. Jambi Dalam Angka 2019. Badan Pusat Statistik Provinsi Jambi. Jambi.

Badan Pusat Statistik. 2019. Usia Produktif. bps.go.id.

Barnito. N. 2009. Budidaya Tanaman Jagung. Suka Abadi. Yogyakata.

Busyra, R.G. 2016. Dampak Program Upaya Khusus (UPSUS) Padi Jagung Kedelai (Pajale) Pada Komoditas Padi Terhadap Perekonomian Kabupaten Tanjung Jabung Timur. Jurnal Media Agribisnis (MeA) Vol.1 No.1 : 12 27.

BPTP Kalimantan Timur. 2014. Sejarah Tanaman Jagung. http://kaltim.litbang.pertanian.go.id/ind/index.php?option=com_content\&view=article\&id=600:sejarahtanamanjagung\&catid=60:pernik\&Itemid=97. Diunduh pada tanggal 10 Februari 2020.

Dinas Pertanian. 2019. Dinas Pertanian Tanaman Pangan Dalam Angka. Dinas Pertanian Kota Jambi. Jambi.

Dinas Tenaga Kerja dan Transmigrasi. 2018. Provinsi Jambi.

Firdaus M. 2009. Manajemen Agribisnis. Bumi Aksara. Jakarta.

Ghozali, I. 2008. Aplikasi Analisis Multivariate Dengan Program SPSS. Undip Press. Semarang.

Gujarati, D. 2003. Ekonometrika Dasar. Terjemahan. Erlangga. Jakarta.

Hernanto. F. 1996. Ilmu Usahatani. PT. Penebar Swadaya. Jakarta.

Hutagalung, M. 2007. Dampak Peningkatan Harga Beras Terhadap Tingkat Kesejahteraan Petani Pada Beberapa Strata Luas Lahan. Skripsi Departemen Sosial Ekonomi Pertanian Fakultas Pertanian Universitas Sumatera Utara. Medan.

Intriligator, M.D. 1978. Econometric Model. Techniques. and Applications. Prentice Hall Inc. New Jersey.

Kasim. S. A. 2006. Ilmu Usahatani. Fakultas Pertanian Universitas Lambung Mangkurat. Banjarbaru.

Kementerian Perindustrian. 2020. Pohon Industri Jagung. https://kemenperin.go.id/pohon-industri. Diunduh pada tanggal 10 Februari 2020.

Kotler, P \& Armstrong. 2010. Principles of Marketing, thirteen edition. New Jersey: Prentice-Hall, Inc.

Kotler \& Keller. 2012. Marketing Management, 14th. Person Education.

Koutsoyiannis. 1977. Theory of Econometrics: An Introductory Exposition of Econometric Methods. Second Edition. Macmillan Publishers Ltd. London.

Lumbanraja, M. 2013. Pengaruh Kredit Pertanian Terhadap Kesejahteraan Petani Kelapa Sawit Di Kabupaten Labuhan Ratu Utara. Jurnal Ekonomi dan Keuangan Vol.1 No.10 Universitas Sumatera. Medan.

Mc. Williams. D.A. D.R. Berglund and G.J. Endres. 1999. Corn Growth and Management Quick Guide.

Poerwadarminta, W.J.S. 2003. Kamus Umum Bahasa Indonesia. Balai Pustaka. Jakarta.

Purwono dan R. Hartono. R. 2007. Bertanam Jagung Manis. Penebar Swadaya. Bogor.

Rizieq, R. 2010. Dampak Subsidi Pupuk Terhadap Kesejahteraan Petani. Jurnal Soca Vol. 10 (2) : 121 - 127. ISSN: 1411-7177.

Rukmana Rahmat. 2010. Jagung Budidaya, Pascapanen, dan Penganekaragaman Pangan. Aneka Ilmu. CV. Semarang.

Santoso, S. 2000. Buku Latihan SPSS Statistik Parametrik. Elex Media Komputindo. Jakarta.

Sari Dewi. 2010. Mengembangkan Pendidikan Berkarakter Melalui Implementasi High-Tech and High Touch Pada Pendidikan Anak Usia Dini. Dalam Procceding Seminar Aktualisasi Pendidikan Karakter Bangsa. Universitas Pendidikan Indonesia. 
Soeharjo. A dan Patong. 1977. Sendi Sendi Pokok Usahatani. Departemen Ilmu Sosial Ekonomi Pertanian. Fakutas Pertanian. Institut Pertanian Bogor.

Soekartawi.1990. Teori Ekonomi Produksi dengan Produk Bahasan Analisis Fungsi Coob-Douglas. PT. Rajagrafindo Persada Jakarta.

Sitorus. M. 2009. Spektroskopi (Elusidasi Struktur Molekul Organik). Graha Ilmu. Yogyakarta.

Suprapto dan Marzuki. 2005. Botani Tanaman Jagung. Universitas Sumatera Utara Press. Sumatera Utara.

Sudarman. A dan Alghifari. 2011. Ekonomi Mikro-Makro. BPFE Yogyakarta.

Tjakrawiralaksana, A. 1987. Ilmu Usaha Tani. Jurusan Ilmu Sosial Ekonomi Pertanian. IPB. Bogor.

Undang-Undang Republik Indonesia Nomor 11 Tahun 2019 Tentang Kesejahteraan Sosial. 19 Tentang Kesejahteraan Sosial. 